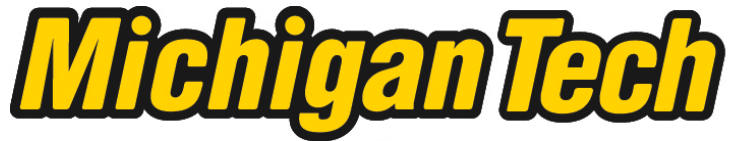 \\ Michigan Technological University Create the Future Digital Commons @ Michigan Tech
}

Dissertations, Master's Theses and Master's Reports - Open

Dissertations, Master's Theses and Master's

Reports

1998

Becoming most fully ourselves : gender, voice, and ritual in dissertations

Marilyn Vogler Urion

Michigan Technological University

Follow this and additional works at: https://digitalcommons.mtu.edu/etds

Part of the Rhetoric and Composition Commons

Copyright 1998 Marilyn Vogler Urion

\section{Recommended Citation}

Urion, Marilyn Vogler, "Becoming most fully ourselves : gender, voice, and ritual in dissertations", Dissertation, Michigan Technological University, 1998.

https://doi.org/10.37099/mtu.dc.etds/95

Follow this and additional works at: https://digitalcommons.mtu.edu/etds

Part of the Rhetoric and Composition Commons 
This dissertation, Becoming Most Fully OuRselves: Gender, VoICE, AND RITUAL IN DISSERTATIONS, is hereby approved in partial fulfillment of the requirements for the degree of DOCTOR OF PHILOSOPHY in the field of Rhetoric and Technical Communication.

DEPARTMENT - HUMANITIES

$\begin{array}{ll}\text { Dissertation Advisor } & \text { Laurie Anne Whitt } \\ \text { Committee } & \text { Jennifer Daryl Slack } \\ & \text { Carol A. MacLennan } \\ & \text { Elizabeth A. Flynn } \\ & \text { Marilyn M. Cooper } \\ \text { Peer Reader } & \text { Stephen K. Jukuri } \\ \text { Department Chair } & \text { Cynthia L. Selfe } \\ \text { Date } & \text { 21 May 1998 }\end{array}$




\title{
BECOMING MOST FULLY OURSELVES: GENDER, VOICE, AND RITUAL IN DISSERTATIONS
}

By

Marilyn Vogler Urion

\author{
A DISSERTATION \\ Submitted in partial fulfillment of the requirements \\ for the degree of \\ DOCTOR OF PHILOSOPHY \\ (RHETORIC AND TECHNICAL COMMUNICATION)
}
MICHIGAN TECHNOLOGICAL UNIVERSITY
Houghton, Michigan

1998 


\begin{abstract}
The writing and defense of the dissertation serve both as demonstration one is able to do the work of a scholar and as a rite of initiation. In contrast to much academic writing, dissertations generally adhere to narrowly conceived notions of academic discourse. I explore this within the context of an academic community in which under-representation remains a serious issue.

This dissertation is about women writing dissertations. I draw from conversations with fifteen women in, or beyond, the process; friends' anecdotes; published accounts; and, autobiographically, my experience. I suggest the dissertation's initiatory role is at least as important as its scholarly role; during the process one establishes a sense of self as scholar, writer, and researcher.

Students come to the dissertation with some notion of self as writer and scholar-a culturally negotiated sense that is more, or less, congruent with the culturally established self required for successful completion of the dissertation. The degree of congruence (or alternatively, harmony and dissonance) shapes the process of doing a dissertation. I argue that both the community and the language in which dissertations must generally be written are gendered masculine. Negotiating a voice that is acceptable in a dissertation while maintaining fidelity to a sense of who one is seems more problematic as one's distance from the center of dominant culture increases.

Believing that agency lies in altering the reiteration of such processes, I worked with my committee to find ways to alter the process yet still do a dissertation. I write in a variety of voices-essay and poetry as well as analytical-play with visual qualities of text, and experiment with non-verbal interpretations. These don't exhaust possibilities, but do give a sense of how the rich variety of expression found in academe can be brought into the dissertation. I thus demonstrate that one need not reconstitute herself through characteristic academic discourse in order to be initiated into the community of scholars. I suggest both the desirability of encouraging flexibility in the language, form, and process of dissertations, and the theoretical necessity for such flexibility if the academic community is to become diverse.
\end{abstract}


So, the goal is to begin your work honestly by presenting yourself and your task in some way that will make sense to group members.

- Michael Agar (61) 


\section{ACKNOWLEDGEMENTS}

The text is always written under the sweet pressure of love.

How to acknowledge all the voices that have contributed to this project? Impossible task. Instructors of the course work on which this project builds, authors read \& cited and read \& uncited, posters to e-lists, presenters at conferences, casual acquaintances, dear and good friends, good and hearty adversaries,... Among them: Lois and David and Seth and Franklin who have tolerated, even encouraged, my slipping outside of traditional familial boundaries; participants in this study who have taken such time and care in sharing stories; the grad students at Michigan Tech who people the world I have so enjoyed sharing, and especially Peggi and David and Anne and Susan and Jodi, ... and Nancy, without whom, page 338 may never have gotten printed; the consultants in the CCLI, who've kept the machines in/on line as l've pushed them toward/over the edge; friends at Winona State who embody great caring-Colette, Helen, Lisa, Cindy, Beth, Nancy, Erin, Sue, Susan, Suzanne, Amy, ... and Tim, who loaned me his copy of Women's Ways of Knowing. But lists are not up to the task.

I came to Tech unsure I would finish. I'm not sure I could even imagine "finishing" a PhD. The faculty in the Department of Humanities extended such commitment and support to me that after a year among them, I could not imagine not finishing. They have, in the intervening years, repeatedly extended boundaries, stretched the ordinary, and negotiated possibilities; they have nudged, sometimes pushed, when I have been hesitant; they have shared books, spare rooms, meals, hugs, talk \& silence, hours \& whole days.

Since my appointment as Graduate Fellow in the Office of Research and the Graduate School, I have been fortunate in having Sung Lee as a mentor. And with much appreciation 1 acknowledge the good and enthusiastic support I continue to receive from the folks I work with in ORGS; they remind me almost daily that what I'm doing matters. And sometimes they laugh at me, which is equally important.

How though, to acknowledge my committee-Laurie, Jennifer, Marilyn, Carol, Beth, Stephen? Their hours, days, patience, impatience, risk, commitment; their collaboration, guidance, trust, \& letting go? Their words and laughter? Their friendship? One study participant wrote urging me not to neglect the piece of the story that says, "It's possible to write a dissertation that empowers and transforms us - that we can emerge whole and glad for who we have become." Perhaps it is enough to say that I emerge from this time glad for who I am becoming, and that these six people have contributed in many varied ways, not the least of which is maintaining the space in which this has been possible. In the absence of adequate words, hugs.

Houghton, Michigan

May 25, 1998 


\section{Offering}

At lalmost] fifty
one of the problems
with going back to school for a Dh.D.
is that it's hard to think
of doing a dissertation
just to be done with it - just to get on with my [ife.
At fift $y$ lalmost]
Tam already into my [ife
and my hours are too few to spend without passion.

And at lalmostl fifty

Tam tired of whitting $m \psi$ voice to fit incongruous spaces

and impatient with softening the edges of what $\mathrm{I}$ say.

At [almost] fift $y$

Tam lalmostl willing to risk revolution -

T am well into my life

and $m y$ words are too man $\gamma$ to write without passion.

And my words, at fifty, are expansive -

9 breathe in and the scent of stars swirls with mockorange.

I reach to pick up a cone dropped by a great white pine

and the tips of my fingers meet the cold at the edge of the universe.

$\checkmark$ bite into the firm, green skin of a ripened pear

and $m y$ tongue recoils at the sharp grit of a falling star.

I sit with my fingers on the keyboard

and words from a thousand generations clamor to be spoken.

At fifty I am willing to risk metamorphosis

and my hours are too few to spend without play.

At [just past] fifty I give you my words.

They are without boundaries

the scent of ripe pears and mockorange

the cold of hyperspace,

the sharp grit of falling stars,

words of a thousand generations' passion and play clamoring

at the edge of the universe -

revolution

for your pleasure. 
PRELUDE TO A DISSERTATION ...

[1993]

Gap

unfilled time between birth and motherhood - placenta still attached

time

between conception and bindery - placental committee tethering my words

time

between year's end and year's beginning

chaos

when priests walk in rags and peasants ride asses

I am neither. I fly.

My maternal grandmother's only son was stillborn. She was never forgiven her body's resistance to patriarchy. I have borne two sons and though I love them it is time for a daughter

- one who will speak wildly with a woman's tongue and be heard

- one who will dance unafraid in moonlight, sacred baptism of the lunacy which is her birthright.

[Nine million women, some say, were murdered in European witch-hunts. My friend Mary D. was not permitted to stage Vinegar Tom at the small Catholic college where she teaches theatre. It is time for daughters!]

Articulation is the issue

[my own articulation ...]

tau[gh]t

I am stretched on the rack of the academy

Crow calls stretch across the land

taut between the topmost branches of dead trees

and the peaks of rooftops.

The crow can loose her voice and fly.

1 am tethered by loving hands, and hooded.

What faith falconers must have waiting the return of the falcon from her maiden voyage.

What certainty in over-determination.

What irony, that unclipped wings return to the tether. 
A Note for Readers

This is not a traditional, chaptered dissertation. Rather, I have shaped it with the metaphor of a musical concert, ordering pieces more for contrast than for coherence. Except for these introductory pages, which I hope will allay whatever frustration there is in not finding the expected forms, there is little beyond an aesthetic juxtaposition of texture and tone that dictates the order in which the pieces are presented-that, and to some extent the chronology in which they were written. And so there is, I hope, no linear imperative that seems to dictate you begin at page one and follow through in sequence. Most sections, in fact, will stand alone, each with its own argument. And at least one has been published separately.

It may be important, however, that you read all of the sections if the overall argument concerns you. My second hope is that the integrity of this overall argument depends on wholeness and multiplicity rather than linearity. In this, it is a demonstration of itself-of the notion that legitimizing polyvocality is necessary to academic integrity.

The sections are roughly patterned after musical forms-you will find, for instance, a "Passacaglia and Fugue on Autobiography" and an essay titled "Road Poems Overture." In some ways, these forms reflect the process of my work. There is a rondo, for instance, an early, four-page essay on what I imagined the project would encompass. These four pages are elaborated in structurally complex footnotes, reflecting my growing acquaintance with the issues. I will, having learned the importance of informative introductions from J, friend and conductor whose dissertation I read in its early drafts, provide notes about the various forms as they occur.

A couple of other explanations may also be useful to your reading. I refer throughout to a number of different people, sometimes by name, sometimes by initial. I have generally used names in the literary essays; I have used names, for instance, for family, neighbors, high school teachers, and friends when the context is not related to my dissertation (or their dissertations). 
Outside of the literary essays I have used only a first initial for friends and family if the use is directly connected to their comments about my (or their own) dissertations. I have also used first initials for committee members and other faculty and grad students at Tech. However, initials overlap-for instance, " $L$ " may sometimes refer to my advisor, at other times to someone else whose name begins with that letter.

I have used pseudonyms for study participants where I am telling an extended story. I have used "SP" or a descriptor, e.g., "another woman" or "a woman in nursing," to mark other references to study participants.

In some places, in order to bring some consistency to paragraphs or pages, I've made exceptions to these general guidelines.

About the study participants themselves-

They come from a wide variety of disciplines, but do not "represent" those disciplines, that is, they aren't necessarily representative of students in those fields. They are self-selected, having either chosen to respond directly to my e-list requests for dissertation stories, or having been urged by friends to contact me. Or I have gone to them, having been told I have to talk to so-andso.

When I put out a request for dissertation stories over three e-mail lists, about fifty people responded; of those, some thirty have corresponded with me over the past two-and-a-half years about their experiences writing and defending dissertations-sixteen at some length. I have met with one of the women over coffee at a conference; ten have participated in hour-long telephone interviews; and one has regularly read sections of my dissertation as I've drafted them. I have talked with women in engineering, biology, philosophy, composition, history, psychology, political science, literature, education, nursing, social work, theatre, and religion. Some received their PhDs over a decade ago; others are still working on proposals. I have collected stories from friends and colleagues-mostly women but a few men as well. All told, I share here from the stories of eighteen major contributors and perhaps ten to twenty others. 


\section{Program Notes}

There has been a certain, continuing reluctance on my part, ambivalence perhaps, with pursuing this Ph.D.
am•biv•a•lence $\backslash$ am-'biv- - -lən $(\mathrm{t}) \mathrm{s} \backslash n$ [ISV] 1 : simultaneous attraction toward and repulsion from an object, person, or action 2 a : continual fluctuation (as between one thing and its opposite) $\mathbf{b}$ : uncertainty as to which approach

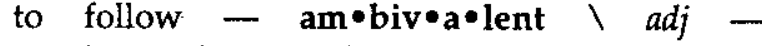 am•biv•a・lent $\bullet$ ly $a d v \quad$ (WNC)

Pursuing, I am yet to become; achieving I will have become what I am not yet. And it-becoming a Ph.D. that is-isn't something one can do and then decide to undo-like a getting married, for instance, or getting a haircut. It's a terminal affair. And too, I am supposed to come out of the process itself, the becoming, somehow changed, though I'm not sure precisely how. Perhaps not knowing the how is part of the reluctance. Perhaps not knowing whether I want to be changed is part of the ambivalence.

Me (October 1994): It seems problematic to assume that women will not have, themselves, been changed in the process of legitimizing their voices to speak ...
M: But you're always being changed-this is a condition of existence.

Is controlling change a Marijo, a student worthwhile focus of attention?

in the Feminist

Theory class I taught, talked about the

connection to her working-class roots that she knew would be broken when she finished her bachelor's degree - about the ties that would be severed. Mostly that quarter, Marijo fought the notion of losing her own, working-class voice in acquiring an "academic" one. Becoming bilingual, she thought, was an acceptable alternative.

\footnotetext{
${ }^{1}$ I was told by a colleague, for instance, that no matter how good a teacher of first-year English I was with a master's degree, l'd be a better one with a Ph.D. I think sometimes I'm not as good, but perhaps that's temporary, because I'm distracted with getting the degree. Five years, though, is a long time to be distracted: 1215 students worth of college English classes by my tally.

September 1996. I have stepped out of teaching for now, and have taken on a fellowship in the Graduate School in order to finish my dissertation. I found teaching while only half-focused less than satisfying. And I found writing while only half-focused less than satisfying. Mostly, I found writing away from the community difficult.

2 Perhaps being almost [now over] fifty, white, middle-class, and married to a tenured full professor is part of the reason I can afford to be reluctant and ambivalent at all. Even as a woman, and as a teacher of courses within the Women's Studies Program when l'm not teaching first-year English, I write from a position of relative privilege.
} 


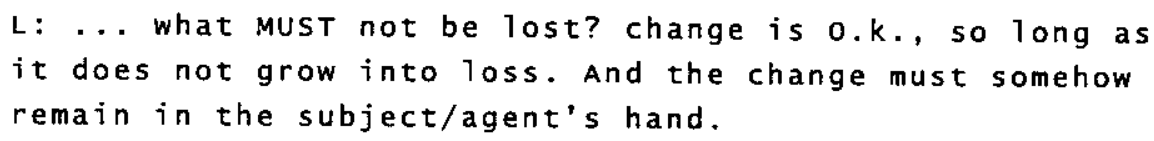

My friend $C$ asks me whether all education is not becoming something else and in that, an alienation from oneself? Do butterflies, I wonder, recognize themselves in the caterpillars they were?

fat plodding worms that spend their days dezouring elemental cellulose or tadpoles that come eventually

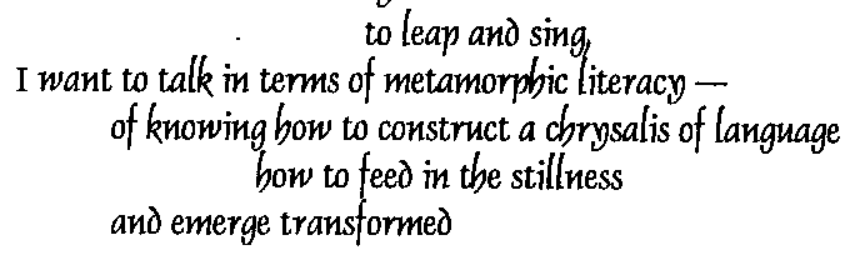

Ambivalence, too, about what 1 do with the degree once it's in hand. There are three schools in the area where my husband is tenured and invested in the retirement system. I might teach there, but finding a on there being one for matter given how hard disciplined and friends who have lived Weeden, though they've Salina, Kansas, and have Fort Hays where Rosalie separately for several finished her Ph.D.; Colette he in Tucson for two Winona where she had Loss is perhaps the ultimate philosophical problem - and death, only incidentally and to the extent it is experienced as loss by those who remain alive. ... The more precious a thing is, the greater becomes its power to hurf us by simply being absent.

$$
\text { - Jan Zwicky (164) }
$$

tenure-track job depends which I qualify-no small

l've worked to be uninterdisciplinary. We have apart: Rosalie and now sold their property in moved permanently to

teaches. They lived years while and after she and John, she in Winona, years, until he came to received tenure in the

history department (After teaching several years as an adjunct, he is now in a tenure-track position in history as well.) Other Winona people: Margaret, resident scholar, whose husband lives in Sierra Vista, Arizona; Sally, whose husband lives one-hundred miles away in the Twin Cities and teaches geology while she teaches mathematics. (He retired this year and moved into the house they'd built in Winona; they had lived apart for almost a decade). Cindy and Beth, who lived apart for a year; Beth is leaving a tenure-track position to go with Cindy when she moves West for graduate school. And Michigan Tech people: Ted, whose wife works in Washington, D.C.; And Laurie, whose husband Alan moved eight hours away over the summer to a teaching job down state. How do we deal with these issues? Not well, I think. A request for documentation of institutional policies for partner hiring posted to a women's studies e-list received no replies. But then, Susan tells me of friends, both "workaholics," whose marriage improved upon separationwho spend the school year apart except for breaks, who devote without guilt their winter time and energy to their teaching, their summers to "romantic honeymoons." And so my husband Dave and I talk around the edges about the possibility of a long-distance marriage ... 
l've told this story to at least some of the people involved:

How I wasn't really thinking at first l'd finish this degree, ${ }^{3}$ that a year in Houghton would be good fun, and that 1 liked being a student, but to be starting a Ph.D. at 47 ...

How I at some point came to feel such a commitment on the part of people at Tech to me. Bits of conversation, comments on my papers, a texture in voices, 50 many examples...

How I came to appreciate what a decision it had been to admit me. "I knew we made the right choice." I hadn't even thought about the possibility that l'd been admitted where others hadn't.

How I could not renounce that commitment by leaving after my year: "It's been fun, but ...." My admission had been a commitment on my part as well.

And so I began to think I might actually write the dissertation l'd jotted early thoughts about: September 29, 1992: Gendered language as a second language-

Can we distinguish between the writing of feminine vs. masculine text, not knowing the writer, compare psychological profiles with the writing samples, collect anecdotes about how these people learned to write, what modes they are comfortable in, etc.?

What does it do to women to have to speak publicly in a foreign language?

October 12, 1992: How is the authority of one's right to be an author transferred? Think of T and his short sentences. Do we realize our own authority in a "moment" of openness? Do we grow into it, gradually realizing authority in a sequence of situations?

RELUCTANCE At first, it was knowing I didn't want to spend several years writing a dissertation like those l'd heard about: D's, written to be done with it, his advisor chosen based on the number of students he'd seen through the project successfully, D's own interest then, and since, in other areas; $V$ 's shelved upon completion, not looked at since, a project taken on because of the interests of the advisor she worked with; A's and the difficulty she's having scheduling a defense date, getting the committee to agree on revisions; M's [angry] decision to

3 I routinely do not finish things \& spent the summer of ' 92 building a stone wall in my back yard. I spent fall term writing about it:

November 1992: But my wall is not yet finished off: the top is ragged, uneven, precarious, evolving. l've decided I should eventually cement the capping stones in place-secure them against weather and feet and forces that don't love walls. But that will be final and difficult.... And 1 wonder if incompleteness is not part of my very nature.

After reading my essay in Blue lce, $M$ talked to me about cementing in the top course of stone, said she didn't think it was necessary, said her father built stone walls with loose top courses that stood solidly in central Pennsylvania. I finished the wall the summer after I returned to Winona from my year at Houghton. Bob, my neighbor, had a load of sand and dirt he wanted to be rid of-it became the fill I hadn't gotten from Romy Baker; I made several more trips for stone, but it felt different, my having written about it and all I suppose; I didn't cement in the top course, but stuffed the cracks with sphagnum and planted them with Sedum album murale and lemon thyme. It seems solid enough, even when my son tests it by doing acid drops on his skateboard from its height. $M$, wall-builder and artist, is among those voices for/with whom I write this dissertation. 
write a second dissertation after the first was taken over by an advisor. At mid-life, I am reluctant to spend much time or effort on anything I don't, to some extent, enjoy-though, too, I've learned, by mid-life, to enjoy a number of things simply because they have to be done. But I don't want, afterward, for my diss to simply sit on a shelf, and certainly I don't want to be angry about it. Neither, however, am I laying the foundation of a career-l am, I suppose, adding a room to an already fairly comfortable house, and in that there is a great deal of freedom. It is also the case, however, because 1 have lived in the neighborhood for awhile, having written and taught writing for much of my adult life, that I am perhaps more acutely aware of what the consequences of adding that room might be. I am, as James Slevin explains, more critically able to grasp my situation and thus am more able to be an agent "in reconceiving and shaping that situation." 4 write and watch myself write at the same time.

For a long time l couldn't imagine finding a dissertation topic. This is, especially in humanities l've since learned, a most difficult hurdle. I am amused both to learn that in some fields, particularly the sciences, many students enter grad school knowing, or find out with their first lab appointment, what their dissertation will be, ${ }^{5}$ and to realize that l've come around myself to address an issue that in some ways has been with me since before my admission to Tech's program-as if I too had entered grad school knowing what my dissertation would be-but for different reasons.

October [?] 1992: I met with my initial advising team some time after fa!l term was underway and told them I was interested in what seemed to me a necessary bilingualism in women-a notion that women going through school learned a masculine language and that, if they learned it well, it was to the detriment of their own mother / woman's tongue," that they functioned much like ESL students. I talked, too, about my belief that there were things that could not be translated, things that could be said in one language and not another, and wondered [silently] what things I might say if I spoke a woman's language-for I felt l'd never learned it, having been well trained during high school in the argumentative language of debate by Miss Scott and the linear language of thesis $\longrightarrow$ proof papers by Arch Wrisinger.

But I was also writing, for the first time in my life, ${ }^{6}$ a "personal essay." The opening lines came one night as! was going to sleep

${ }^{*} \mathrm{M}$ : Which one is this?

Do we each have one?

I'm sure I've mentioned this before, but this notion seems awfully essentialist to me.

Me, 10.17.97: I did say this; probably wouldn't now-

${ }^{4}$ (Slevin 1989, 33). Noted in an article written by Shireen Carroll, Wendy Carse, and Annette Trefzer (1993) as they completed their dissertations. They ask a question close to my own:

How can we hope to participate in the transformation of the profession-certainly a primary goal of feminists in academe-when we are ourselves in the process of transformation, struggling to create professional selves in an institution that marginalizes us while dictating the shape of those future seives? (64)

5 I asked $\mathrm{L}$ at one point if she wouldn't simply suggest a topic for me to write about. She would not.

6 In truth, I had probably written others. One in particular, about a former teacher. But that assignment had been to write an "expository" essay, and I wasn't sure I knew what an expository essay was and so was more worried about whether 'd understood the assignment than whether I had written a good paper. I didn't experience the same uncertainty about what I was to do in R's 
and so I got up, turned on the computer, and typed them out in a narrow column down the left side of the screen. The rest of the essay wrote easily and well, and the writing involved little of the struggle that generally went into my academic papers. (How hard to get "papers" to fit into a linear argument with a beginning and an end-what discipline it required.) And I liked the voice I heard myself speaking. And then A's Lunch Inventio presentation on multi-media: I already knew I didn't want to do a dissertation that could be bound in black buckram, stamped with gold letters, and shelved somewhere to get dusty. Paisley suits me, but with A's demonstration, other possibilities: sound, graphics, hypertext ... a CD-rom! P laughed at the consternation that would erupt at University Microfilms. ${ }^{\circ}$ I knew (sort of) what I wanted my dissertation to do [or perhaps, at this stage, not do], though 1 had no idea what it would be about. Reluctance morphed into gleeful anticipation ...

Years ago I taped to the side of the file cabinet that stood beside the desk where I worked in the library of the National Academy of Sciences a small rectangular piece of paper on which 1 had typed:

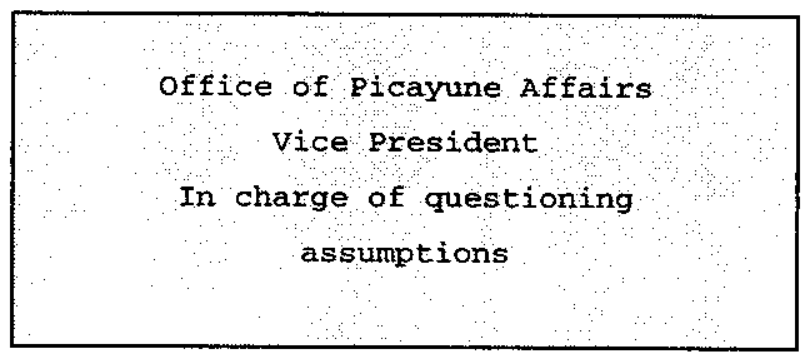

Perhaps my dissertation had begun then ...

Literary Non-Fiction class. Not again until L told me l ought to write at length "conceptually" about the things I was reading for her. "I'm not sure," I wrote to her, "I know what it means to write 'conceptually'." And then C's suggestion that I would, she supposed, need to write analytically at some point. Unsettling to think one knows how to write and to find there is 50 much, still, that is mysterious.

- To: "M. . . @mtu.edu

From: Marilyn Vogler urion mjurion@mtu.edu

re: Planning to electronic Dociment subiitissionis

sure! count me in.

At 11:02 AM 10/15/97-0400, you wrote:

$>$ As we move toward electronic submission of theses and dissertations, >input, planning, experimenting, prototypes, etc. must be developed.

> You 5, Marilyn, Brett, Kirk, Cindy, and Deb,

>have been identified as students and faculty likely to be

interested.

$>$

$>$ If this is true, would you be able to meet with

$>$ Nancy szofran and Lee Durham, of the Library, and me

$>$ sometime next week, to get a sense of needs and directions

>and to start out with a mind for the different platforms and styles

$>$ we will need to serve?

What an amazing distance we are from five years ago! 
But watching the other grad students around me, I began to sense the ritual nature of it all of committee selection, of writing, and revising, and of the oral defense, and my reluctancetransformed-to-anticipation became doubt about the wisdom of going through with the ritual, with this initiation to become a member of a community I had my doubts about joining ${ }^{7}$ -

7 I came, I think, to understand part of my reluctance talking with $C$ as we walked back to our room at the RoadStar Inn one night during a women's studies conference at Stevens Point, Wisconsin. I talked about the change of status I had felt at WSU after finishing my master's degree - how, while I was a student I felt "golden." Three teachers had separately told me that papers l'd done for them had the potential to be publishable. l'd asked my advisor about it, feeling surely I couldn't be that good. When I became an adjunct, and later a fixed-term member of the same department, however, it seemed I could do little right, at least in some eyes. My performance was "adequate for rank and position."

Wife of a faculty member tenured in another department, 1 wasn't going off to somewhere else after a couple of years. I would be there, wanting to teach, for too long-longer than two years, certainly, that the customary duration of a fixed-term person's stay in the department. I wrote to the union president. Questions came up about how the contract language had been interpreted 50 as to limit a person's stay in the department; union folk from the head office became involved; Meet and Confer-the official point of contact between faculty and administration-and it came down to the fact that a person could teach for any number of years as a fixed-termer-the issue had been grieved at another campus. This set aside the department's policy of hiring a transient population to teach freshman composition. Though it came up again later when I was told, submitting my application, that it was the last l'd be eligible to submit since l'd taught my four (no longer two) years! A second grievance, also decided in my favor, but a rift between me and the department. And about other topics I spoke up and out in department and committee meetings. It seemed to me I was doing what I had been trained to do-close reading of the contract and other texts, effective argumentative writing to state a position. Using my voice. Things I was to teach, but not do.

How, I asked $C$, though not expecting an answer, would my relationship with the people at Michigan Tech be changed by my completion of the degree? When one becomes a "colleague," does one also become an adversary? Do colleagues nurture one another as they nurture students and advisees? What sort of friendships does the academy allow for? It is not difficult to imagine these relationships constructed through and by the language with which one enters the community - the dissertation - the moment of proving oneself ... what? ... better than? ... more original than? ... more insightful than? ... an adversary of? ... or are there other possibilities? But perhaps the tensions I felt at WSU were incestuous ones brought on by my being hired into the department from which I had received my most recent degree.

7.15.95: Reading Erving Goffman's The Presentation of Self in Everyday Life, I think it more likely a conflict brought on by sharing secrets between backstage and frontstage.

10.18.97: [Agenda item \#8 of a local Academic Forum meeting held July 23, 1997] "National Survey of Chief Academic Officers on the Hiring of Inbred Faculty at Institutions of Higher Education Summary Results."

* This comment was made by a colleague on my annual review. Another, who had commented the previous year that 1 was doing more real research than some of the 
would I become quarrelsome, impatient with students and quick to judge them inadequate, lethargic in my scholarship; would I be like a colleague of D's who, after ten years had not yet taken up writing again because he was still exhausted, he explained, from his dissertation? Two of the participants in my study have asked straight out (if haif in jest) why, after hearing all these stories, I even want to be an academic. Like the tongue to a sore tooth or fingers to scabs, I was drawn to remember those academics whose attitudes I found distressing rather than those who were valued mentors. But what else does one do besides teach?

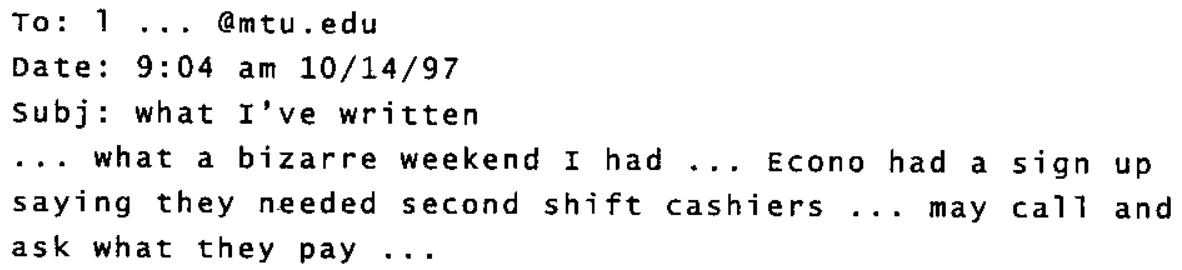

It is somewhat disconcerting to hear apparently successful women say they'd be glad to leave academe-not an uncommon feeling from what I hear. One of the women l've been talking with, for instance, who completed her PhD in philosophy in 1994 and is in a tenure-track position about which she said, "I couldn't have written a better job for myself," also said, "I would be more than content ... to get to the point in my life where I could leave the academy all together and do what it is that I do on a more popular basis. I think I would be much more effective and l'd be happier."

I have generally been ambivalent about transforming rituals, thankful on more than one occasion that my mother did not have me baptized, a fact that probably had more to do with my being born in Fairbanks, Alaska, than with her religious convictions, but a fact nonetheless. She had been baptized twice-once, as a baby, into the Swedish Lutheran church in Kansas City, Missouri, and a second time when she was a teenager in the culmination of a week-long revival meeting at the Presbyterian church down the street. I don't know whether my father was baptized. But I was not. ${ }^{8}$ Neither have I ever had tarot cards read for me; 9 I believe too much in their veracity. ${ }^{10}$ Or in the power of the mind to make happen what it believes is supposed to

tenured faculty in the department, said, on reviewing my application to teach again, that it appeared I "did little of consequence in the classroom." But in retrospect, and to be fair, I have probably been more consistently uppity than I admit, and many of the members of the department in which I taught have been more consistentily supportive than l've suggested. It has taken me a long time to appreciate this. And it remains that as friends in other departments go off to get PhD's they return, inside candidates, to tenure-track positions, while I remain[ed] tenuously fixed-term. Sometimes I am angry about this.

${ }^{8} \mathrm{C}$ : I find great meaning in rituals of kinds, which is why I practice Judaism the way I do. Is there a correlation between comfort w/ritual \& comfort w/ "the academy"?

9 I was surprised to learn that $J$ reads tarot cards! She is one of the voices l've asked to join my committee. Perhaps, after l've finished with this, I will ask her to read them for me.

to $\mathrm{C}$ : Worried about losing free will, self-determination, innocence of the future?

Me: l've never been drunk, either. 
happen. Nor had my palm read. Although I played once with the 1-Ching, and I sometimes read the horoscopes printed in the morning paper (though not as regularly as my mother, who always tells me on days we have breakfast or lunch whether my day is to be a good one or not).

Me: January 23, 1933 [hmmmm ... sic]

HU 588 paper \#2

The transmission model is the controlling model in limiting the margins within which ritual may be shaped. Those who hold power and define ritual transmit to those who form/maintain the skin of my map [of ritual] ... the patterns of the rituals and the "meaning" rituals are to have, that is, what they are predictive of in a contingent history.

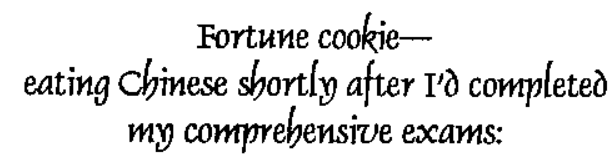

\section{Knowledge Is The Past. \\ Wisdom Is The Future.}

What do we believe is supposed to happen when one enters the community of scholars, successfully writes and defends the dissertation? At that moment of acceptance ... and of proving ...? How like jumping from a tremendous height with only a vine tied 'round the waist. Will I, at that moment I leap into the abyss, at the moment I defend my dissertation, like the me that is asking admission? I have been working very hard to get beyond the adversarial self I had been educated to be." I was convinced even as I completed my master's in 1987 that the language we speak both limits and enables what we can say, and I am coming to believe that the language we speak determines very much who we are. Would I want the identity the dissertation I chose to do enabled? I didn't think I could, as M had suggested, simply do a dissertation to be done with it and then pursue what I really wanted to pursue. The moment of transformation, so I believe[d], would have passed; I would have become whatever it was I was to become; 50 I believe[d].

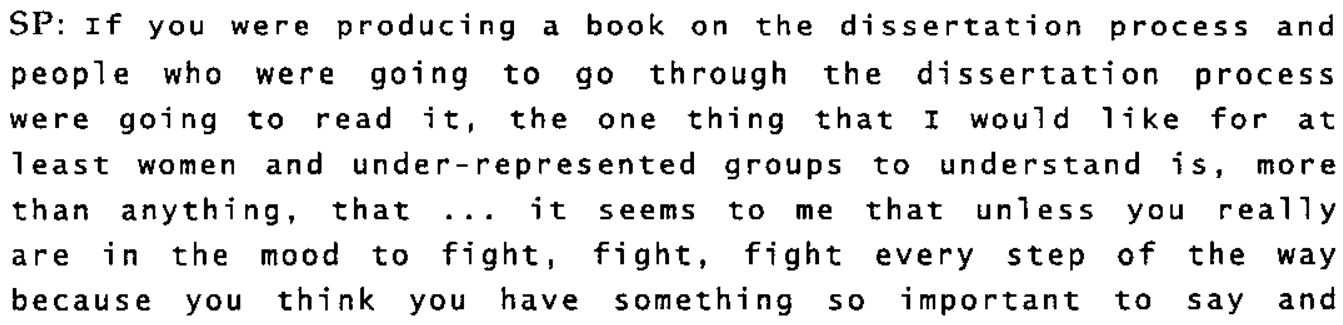

11 4.1.95: Perhaps l'm making progress toward this.

5.3.97: Doubt l've made any progress at all ... find myself unable to taik without being defensive and combative. 


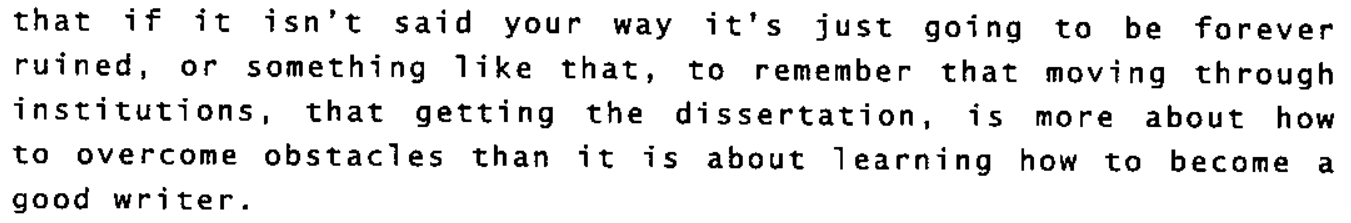

My growing into the notion of writing -into being comfortable with writing - a dissertation, of appreciating my ability to change myself rather than be [passively] changed by it all, and accepting the loss that entails, has taken time-and leeway and tolerance ...

lee •way \lēe- wā $\backslash n 1$ a : off-course lateral movement of a ship when under way $\mathbf{b}$ : the angle between the heading and the track. of an airplane 2 : an allowable margin of freedom or variation : TOLERANCE. (WNC)

tol•er•ance $\backslash$ 'tä-lə-rən(t)s $\backslash n 1$ : capacity to endure pain or hardship : ENDURANCE, FORTITUDE, STAMINA ... 3 a : sympathy or indulgence for beliefs or practices differing from or conflicting with one's own $\mathbf{b}$ : the act of allowing something : TOLERATION $<$ has a large $\sim$ for uncertainty>
(WNC)

... on the part of those with whom I study, those for and with whom I write. 
M: (late January 1993)

[Responding to my "In our writing we confront ourselves."] I'm not sure everyone experiences it this way. If I felt this way, I'm not sure I'd ever write again.

L: (22 August 1993)

Your reader again. Muttering something about "academic concept-dropping".

Says she knows these aren't names, but ...

Ah ... your reader grows insistent. Jrritated even. Says she has never read

Heidegger or Rouse... She's threatening to get up and go home. J'll try to coax her into a coffee break, instead. Will tell her J know the real Marilyn, who will be distressed to learn of this.

B: (late November, 1993)

The collaborative effort was clearly a very productive one. The essay is remarkably coherent and unified. ... I have to admit I wanted to know who the "I's" were, though.

J: (sometime in winter term 1994, probably February)

A very thoughtful paper. I was a little confused about ...

On consent/coercion, you are right to point to the problem/fact of their combination.

But I'm not sure I agree that ...

Ohh ... you open up a long standing debate.... For my own part, ...

Odd, all these disagreements. Oh well, it keeps things lively.

C: (December, 1996)

What you've written isn't itself analytical, but it leads me to think analytically.

S: (January 20, 1997)

I like the response of your geologist friend. ... Your mind latches onto and collects some beautiful associations and metaphorical connections, and I enjoy that. I can never decide, then, if you then need to explain the incredible significance of her response (explanation being a mark of academic discourse) or if people will get it (and accept that you get it) without further discussion. ... In a dissertation, the readers want to know if you really know the significance of what you are saying. They are testing your thought against their own, testing to see if you really are aware of, and in control of, what you are saying. 
... at least, it seems so to me.

M: To me this seems more like being invested in what you're doing. 
Marilyn M. Cooper - Associate Professor of Humanities, PhD, University of Minnesota.

Dissertation: Implicatures in Dramatic Conversations

12Areas of Specialization: Social context and writing, writing pedagogy, [critical and postmodern theory]

${ }^{13}$ Current Research: Marilyn's research "stems from interests in the ways language works, more specifically how a flexible, dynamic, but finite set of symbols are used to mediate personal relationships and social goals. Particular attention is paid to the relationship between language and social structures in reading and writing."

Elizabeth A. Flynn - Professor of Reading and Composition, PhD, The Ohio State University. Dissertation: Feminist Critical Theory: Three Models

Areas of Specialization: Gender and language use, writing in engineering, Virginia Woolf, reader response theory

Current Research: Beth's work “focus primarily on literary studies and composition studies with special emphases in feminist approaches to reading, writing, and teaching and writing in engineering. She is especially interested in situating these theories in relation to explorations of modernism, anti-modernism, and postmodernism."

Stephen K. Jukuri - Doctoral Candidate in Rhetoric and Technical Communication, Michigan Technological University

Areas of Specialization: A fellow PhD candidate who is not yet, and perhaps never will be (with any luck), specialized (e-note, March 28, 1998)

Carol A. MacLennan - Associate Professor of Anthropology, PhD, University of CaliforniaBerkeley. Dissertation: Plantation Capitalism and Social Policy in Hawaii

Areas of Specialization: Science and technology policy, political economy, American politica! culture, anthropology of industry and capitalism

Current Research: Carol "studies the ways in which citizens, corporations, and government participate in environmental decisions. Her current research examines the historical role of the market and industrial power in shaping democratic participation and the environment. As part of the Environmental Policy Program, she teaches Environmental Politics, which focuses on how citizens and special interest groups compete for power - and a voice - in the process by which environmentai concerns are addressed." (Social Sciences web page: http://uww.s5.mtu.edu/EP/faculty/faculty.html)

12 Areas of Specialization are taken from the 1996-1998 Graduate Bulletin unless otherwise attributed; changes were noted 10 April 1998.

${ }^{13}$ Current research areas are taken from the 1997-1998 Rhetoric and Technical Communication Graduate Handbook unless otherwise attributed. 
Jennifer Daryl Slack - Associate Professor of Communication and Cultural Studies, PhD, University of Illinois. Dissertation: Communication Technologies and Society: Causality and Intervention

Areas of Specialization: Cultural studies; [communication theory]; communication technologies and [culture]; and the environment, [and culture]

Current Research: Jennifer's research "focuses on the relationship between communication and culture and has both theoretical and practical components. Her research deals primarily with the theoretical history and institutionalization of cultural studies; technology and culture; environment, and culture."

Marilyn Vogler Urion - Doctoral Candidate in Rhetoric and Technical Communication, Michigan Technological University

Comprehensive Examinations: Feminist philosophy, composition theory, gender and language.

Laurie Anne Whitt - Associate Professor of Philosophy, PhD, University of Western Ontario, Canada. Dissertation: The Promise and Pursuit of Scientific Theories

Areas of Specialization: History and philosophy of science, philosophy of language, ethics, feminism

Current Research: Laurie's research "primarily deals with issues that lie at the intersection of indigenous studies, science studies, and legal studies. In particular, it addresses the role of power in shaping the interaction of indigenous and Western knowledge systems, and the significance of this for indigenous political struggles. Recent work focuses on indigenist critiques of Western science and intellectual property laws, with emphasis on bioprospecting and the Human Genome Diversity Project. Other areas of research interest include environmental ethics, metaphor, and feminism."

\section{Back}

\section{Table of Contents}

Next 